same species as others found on the Devon coast. This is of some interest, as a recent photograph of a specimen from this same region ${ }^{\vartheta}$ seems more likely to be of $C$. tethys than of $L$. campanulata, to which it, too, is ascribed.

It seems very probable that $C$. tethys has appeared at intervals over a considerable stretch of the east and south coasts of Britain. It remains to be discovered whether it is established there, or whether it is a case of sterile distribution with periodical recruitment occurring from an outside source as a result of favourable circumstances at the time of reproduction. The latter alternative seems the less likely, since so far as is known the planula stage in the development of Stauromedusæ is of short duration, and therefore unlikely to be transported over any great distance.

I wish to thank Mr. P. G. Corbin both for the loan of specimens of Lucernaria and for much helpful discussion and assistance with the literature.

Department of Zoology.

F. SEgRove

University, Sheffield 10. June 6.

"Thiel, M. E., "Scyphomedusae" in "Bronns Klassen u. Ordnungen" (Leipzig, 1936).

" Clark, H. J., Boston J. Nat. Hist, 7, 531 (1863).

von Lendenfeld, Proc. Linn. Soc. N.S.W., 9, 165 (1884).

"Irving, J., Naturalist, 355 and 248 (1913).

${ }^{5}$ Burnley, A. I., Naturalist, 394 (1922).

- Irving, J., Naturalist, 74 (1924).

? Johnston, G., Mag. Nat. Hist. J. Zool., 8, 59 (1835).

"Johnston, G., "British Zoophytes" (1847).

"Wilson, D. F., "They Live in the Sea" (London, 1947).

\section{Uricotelism in the Common Indian Apple-Snail, Pila globosa (Swainson)}

NITROGEN catabolism in animals has been assessed partly by analysis of the excretory products and partly by the identification of the enzymes in the liver or hepatopancreas. Since Strohl reviewed the excretory mechanism in the Mollusca, work on a few European marine, freshwater and terrestrial gastropods has been extended ${ }^{1-4}$, Since no data are available for an amphibious snail and no parallel record for an Indian form, so far as we know, a study was undertaken on the common Indian apple-snail Pila globosa (Swainson). This particular form, besides being amphibious, develops through a cleidoic egg. The most active period of this snail's life is during the rainy season, when it lives in fresh water and feeds and also breeds on the banks. With the approach of the winter it becomes less active and burrows in the mud to estivate for the rest of the year until the onset of the next rainy season.

During the course of the investigations, it was noticed that the uric acid content of the nephridium, which in this snail consists of an anterior and a posterior renal chamber, was rather low in the snails collected from their natural environment during the rainy season-being only $7.68 \mathrm{mgm}$. per gm. dry weight of the tissue in the anterior chamber and almost nil in the posterior renal chamber. After these snails have been maintained in the laboratory in wet jars in the shade for about a month, the quantity of uric acid increased to about $60 \mathrm{mgm}$. per gm. dry weight of the tissue in the anterior, and $14 \mathrm{mgm}$. in the posterior, renal chamber. When some of these snails were allowed to rstivate in the mud in the laboratory for a couple of months or more, the uric acid content of the nephridium gradually increased still further; as was shown by periodic estimations of the uric acid in their nephridia. It attained a maximum of about $102 \mathrm{mgm}$. per gm. dry weight of the tissue in the anterior, and $42 \mathrm{mgm}$. in the posterior, renal chamber, in the snails which had restivated for more than six months.

A few of these rstivating animals with high uric acid content of the nephridium were selected and kept in water in small glass bowls, in which they were left for a number of days and periodically exposed to bright sunlight. They were examined one by one after regular intervals and the uric acid content of their nephridia determined. It was found that the quantity of the uric acid decreased with the length of time the snails were kept in the water (see accompanying table).

\begin{tabular}{|c|c|c|c|}
\hline Feriod in water & $\begin{array}{l}\text { Ur } \\
\text { Anterior } \\
\text { chamber }\end{array}$ & $\begin{array}{l}\mathrm{d}^{*} \\
\text { Posterior } \\
\text { chamber }\end{array}$ & Total \\
\hline $\begin{array}{l}\text { Nil } \\
15 \text { days } \\
21 \text { days } \\
27 \text { days }\end{array}$ & $\begin{array}{c}102 \cdot 38 \\
78 \cdot 3 \\
79 \cdot 04 \\
29 \cdot 88\end{array}$ & $\begin{array}{c}42 \cdot 58 \\
50.38 \\
10.23 \\
\text { Nil }\end{array}$ & $\begin{array}{r}144 \cdot 95 \\
109 \cdot 18 \\
89 \cdot 27 \\
29 \cdot 88\end{array}$ \\
\hline
\end{tabular}

* Uric acid content in mgm. per gm. dry weight of the tissue, Two or three snails were selected for each estimation.

Attempts were also made to see if this uricogenesis in Pila globosa could be correlated with certain enzymes present in the hepatopancreas and the nephridium of the snail. Following the technique of Baldwin ${ }^{2}$ and Sumner and Somers ${ }^{5}$ for arginase and xanthine oxidase respectively, it was possible to demonstrate the occurrence of both these enzymes in the hepatopancreas of Pila globosa in appreciable quantities. However, neither of these enzymes could be detected in the nephridium of Pila globosa. Whether these enzymes could be directly related to the æstivation of Pila is difficult to say ${ }^{3,1}$, and so far it has not been possible to find any appreciable difference in the arginase content of the æstivating Pila and those living in an aquarium. The work is, however, being extended by one of us (B. B.S.).

All our experiments were carried out at room temperature with controls and blanks simultaneously.

\section{B. LAC}

Department of Zoology,

B. B. SAXENA

University, Lucknow. June 6.

' Baldwin, E., and Needham, J., Biochem. J., 28, 1372 (1934).

${ }^{2}$ Baldwin, E., Biochem. J., 29, 252 (1935).

${ }^{3}$ Needham, J., Biochem. J., 29, 238 (1935).

"Spitzer, J. M., "Zool. Jahrb.", 57, 457 (1937).

"Sumner and Somers, "Laboratory Experiments" (Academic Press, New York, 1944).

- Clementi, A., Rend. Acad. Lincei, 23, 517 (1914); 27, 299 (1918).

\section{Ultra-Violet Papyrography: an Automatic Analytical Apparatus using Filter Paper without a Colour Reagent}

A NEW analytical technique using filter paper and termed 'ultra-violet papyrography'1 has been developed in these laboratories (Fig. 1).

The apparatus uses light from the ultra-violet $(2537 \mathrm{~A}$.) to visible region for the four methods : 